Article

\title{
Sustainable People Home-Work Logistics: An Integrated Model of Circular Economy in the Chiampo Valley
}

\author{
Maurizio Faccio *, Serena Finco and Ilenia Zennaro
}

Citation: Faccio, M.; Finco, S.; Zennaro, I. Sustainable People Home-Work Logistics: An Integrated Model of Circular Economy in the Chiampo Valley. Sustainability 2021, 13, 12009. https://doi.org/10.3390/ su132112009

Academic Editors: Claudia Colicchia and Sara Perotti

Received: 1 September 2021

Accepted: 27 October 2021

Published: 30 October 202

Publisher's Note: MDPI stays neutral with regard to jurisdictional claims in published maps and institutional affiliations.

Department of Management and Engineering, Univerisity of Padova, Stradella San Nicola 3, 36100 Vicenza, Italy; serena.finco@unipd.it (S.F.); ilenia.zennaro@unipd.it (I.Z.)

* Correspondence: maurizio.faccio@unipd.it

\begin{abstract}
Logistics activities, e.g., transportations of goods and people, are responsible for at least one-third of energy consumption and Green House Gas (GHG) emissions. About 70\% of them are related to people's mobility, with millions of cars moving every day. The people home-work logistics represents undoubtedly an important part of it since flows are concentrated on fixed time windows (beginning, lunch break, and end of the working day) creating huge traffic congestions and negative impacts on time, economics, and the environment. This study proposes an integrated model, summarized through a methodological framework, where three actors (companies, public administrations and local shops) work together aiming to economically incentivize the use of sustainable mobility systems. Three are the main elements of the proposed sustainable people home-work logistics model: (1) the economic self-sustainability of the incentives, funded in different ways by the actors, (2) the scalability, thanks to the possibility to add new territories to the project and (3) the territorial circular economy generated thanks to the incentive's destinations and the public-private integration. Starting from survey questionnaires and territorial attributes, sustainable mobility ways are defined. Then, participant workers are monitored by activating a mobile app, called Ecoattivi, during their home-work journeys. In such a way, workers can directly analyze their sustainable mobility and reach the possibility to accumulate and spend money in local shops as a function of the saved $\mathrm{CO}_{2}$. On the other hand, companies and public administrations compete in a special ranking for sustainable mobility. The methodological framework has been applied to a real case study in the Chiampo Valley, in the northeast of Italy, where about 10 small towns and dozens of companies in 2020 started the "Bike to Work Valchiampo" project.
\end{abstract}

Keywords: sustainable mobility; homework logistics; circular economy; mobile app

\section{Introduction}

The rapid growth of the world population and economic development cause an increasing demand for vehicle travel in metropolitan areas, and consequently an increase in energy consumption and GHG emission. Logistics activities are responsible for at least one-third of energy consumption and GHG emissions and about $70 \%$ of them are related to people's mobility, with millions of cars moving every day [1]. Freight transport contributes not only to increase economic costs in terms of travel time and fuel consumption but also to increase environmental and health problems. As affirmed in [1,2], the most relevant urban problems are related to traffic congestion and urban environmental pollution. The people's home-work logistics represents undoubtedly an important part of it, with flows concentrated on fixed time windows (beginning, lunch break and end of the working day) creating huge traffic congestions, with a negative impact on time, economics, and environment. Traffic congestion implies not only delays and a negative economic impact, but also poorer air quality, loss of health quality, and delays in evacuations and emergency response [3]. Aiming to reduce traffic congestion that usually occurs during peak periods, the authorities have tried to deploy Traffic Demand Management (TDM) strategies to 
eliminate or shift trips away from congested periods. Peak periods of traffic congestion are often associated with the commuting hours of the morning and the afternoon, i.e., during the home-work logistics. Commuters are used to traffic congestions on their way to workplaces from residential areas during the morning rush hours [4]. In such contexts, TDM strategies may take the form of congestion pricing, incentives to shift travel to offpeak periods or alternative uncongested corridors, flexible work hours, telecommuting, transit subsidies, and ridesharing programs [5]. TDM has become an efficient alternative and cost-effective way to ease traffic congestion since it avoids bottlenecks in the road network; it implies multiple benefits as it provides not only traffic congestion reduction, but also improved mobility options, road and parking cost savings, reduced crashes and reduced emissions. TDM encourages the use of high occupancy modes as preferential parking for carpoolers, promotions for transit, carpooling, biking, walking and flexitime, shuttle service to and from park-and-ride lots [6].

To increase participation in alternative home-work logistics solutions, a new typology of traffic management strategy has been developed, as the Incentive-Based Traffic Demand Management (IBTDM). Incentives refer to positive monetary gains, gift cards, or other rewards, and they contrast with TDM strategies of tolls and congestion pricing, which creates disincentives for motorists to make socially undesirable choices [7]. Travellers can receive rewards for maintaining sustainable travel behaviour such as using alternative modes of transportation [8]. Car sharing, bicycles, public transportation are all sustainable alternatives to reduce traffic congestion. Psychological research emphasizes the importance of incentives such as rewards in promoting long-term behaviour changes, as "carrots versus sticks" [9]. The use of ridesharing modes, even if incentivized, may be difficult anyway; the study of [10] reveals that individuals who have a great need for independence or make additional trips on their way to and from work or frequently stay late at work tend to be less inclined to use ridesharing modes.

This study proposes an integrated IBTDM methodological framework where 3 actors, i.e., companies, public administrations, and local shops, work together to economically incentivize the use of sustainable mobility systems. The sustainable people home-work logistics framework aims to promote workers in using bicycles (and potentially other sustainable mobility systems) for the home-work logistics with incentives that can be used in the neighboring shops. In this way, not only the traffic congestion is reduced, but also it promotes a local circular economy generated thanks to the incentive's destinations; the framework is characterized by the economic self-sustainability of the incentives and the scalability, thanks to the possibility to add new areas to the project. The basic novelty of the research is related to the integration since the framework is intended not only for citizens and public administration but also for local shops and companies. In fact, from the literature, it arises that IBTDM strategies are generally intended for citizens, and they carry out benefits for them and the environment. This works, instead, provides a circular economy with benefits not only for the single citizen and the environment but also for local shops and companies. Participant workers are monitored by a mobile app during the home-work journeys, analyzing the sustainable mobility and proving the possibility to accumulate and spend their gain in local shops. Incentives are a function of the saved $\mathrm{CO}_{2}$. On the other hand, companies and public administrations compete in a special ranking for sustainable mobility. The methodological framework has been applied to a real case study in the Chiampo Valley, in the northeast of Italy, where about 10 different small towns and dozens of companies in 2020 start the "bike to work" project.

The paper is organized as follows: Section 2 reports the theoretical background related to TDM and the home-work logistics while Section 3 presents the proposed Incentive-Based Traffic Demand Management (IBTDM) framework for sustainable people home-work logistics. Section 4 reports the case study data and the first results while conclusions are shown in Section 5. 


\section{Traffic Demand Management Background}

Although integrated multimodal transport systems have emerged in several cities, current statistics indicate that in many regions people are still highly dependent on their private vehicles, while public transport accounts for low percentages of the total number of motorized trips [2-4].

In response to this trend, several initiatives and measures have been considered to promote multimodal transportation, by either raising the attractiveness of public transportation and active mobility or by disincentivizing private vehicle usage [11]. Traffic demand management (TDM) strategies aim to reduce unnecessary private car travel demand and encourage more efficient, environmental protection and energy-saving modes through penalty actions as congestion pricing. The framework of [12] aimed to investigate in which conditions the commuter will change departure time and consequently the departure time adjustment process. The work of [6] evaluated different TDM strategies, divided into Transportation System Management (TSM) and Parking Management (PM); TSM includes carpooling, flextime, biking, walking, etc., while PM includes, for example, pricing, preferential parking for carpoolers, shuttle for park-and-ride lots. Saleh \& Farrell, 2005 [13] investigated the potential impact of implementing TDM strategies on departure times, considering the scheduling flexibility of individuals and non-work activities; their results suggest that for those who have flexible work schedules but other non-work commitments, the timing of their work trip might not be so flexible. The combination of both has a relevant influence on traffic congestion. An important tool for TDM is the use of proactive traffic management systems, based on the prediction models of the network state conditions to detect potential flow breakdowns and consequently to plan alternatives [14-16]. Ref. [17] proposed a pricing framework in which carbon emission costs is considered as part of the generalized cost of travel and based on this, developed a model to optimize consumer surplus, using congestion and carbon emission charges as the control variables. In general, the commonly used TDM strategy refers to toll pricing to reduce traffic congestions [18]; many models have been developed based on this strategy as the one of [19-29].

Unlike TDM, which can be considered a "push" strategy, Incentive-Based Traffic Demand Management (IBTDM) is the newest strategy that aims to reduce traffic congestion using incentives and it can be considered as a "pull" strategy since it attracts participants. The impact of incentives on departure time choices is difficult to quantify; first, using traditional technologies for defining individual departure time changes is hard. Many methods were adapted to analyze travel mode choice are not applicable for the analysis of departure time choice, as departure time is a discrete variable. Moreover, the features of sustainable users may vary a lot regarding travel mode and departure time choice, i.e., users willing to change their travel mode may not be willing to change their departure time [11]. Participation in these projects might be influenced by working time flexibility, constraints in the household and the workplace, and personal motivations [9]. Ref. [4] developed a model for studying the effects of IBTDM strategies on bottleneck congestion; results showed that by providing incentives to shift the commuting public's departure times the queuing delay was reduced. The work of [11] investigated the effects of rewardbased instruments on promoting emerging mobility schemes and active transport; results revealed that participants spend more time in public transport usage and walking during the reward-based period. Moreover, they indicated that rewards could increase individuals' time spent in public transport usage and walking by about $21 \mathrm{~min}$ and $14 \mathrm{~min}$ per day respectively. Finally, it was found that public transport users were mostly motivated by rewards, while car users and walkers were not motivated towards cycling.

Many IBTDM models have been presented and analyzed [30,31]. The model of [32] had a pyramid structure to incentivize commuters to travel at less congested hours and it was applied in Bangalore. The studies of [33,34] analyzed the effects of incentives (money or credits to keep a smartphone handset) that could be achieved by commuters by avoiding peak hours or switching to another mode, or by smart working; the model has been applied in Netherlands and commuters received from $3 €$ to $7 €$ for not driving during peak hours. 
Results indicated that incentives could reduce the amount of peak traffic by $60 \%$. In Germany, a pre-paid bus ticket was offered to travellers to incentive public transportation, and results measure a bus usage increase of $35 \%$ and car trips reduction of $13 \%$ [35]. Ref. [3] studied a model which provides monetary incentives or credits toward obtaining a smartphone as a reward to shift commuters to alternatives modes of travel or less congested period of the day; their results highlight that trip's characteristics, availability of alternative travel mode, household and vehicle availability constraints, and work-related attributes are factors which affect departure time and deeply influence the success of the project.

Ref. [36] proposed a microeconomic model for optimizing a government-sponsored transit incentive program, where riders receive a certain monetary reward once a transit trip is completed; to determine incentives amounts, the government determine the fare and the headway limits for the operator, with an objective of social welfare maximization. Finally, the recent work of [37] used a raffle-based scheme to incentivize users to change their travel choice, by giving out credits that can be used to enter a lottery instead of fees or credits. In the project, two stages were defined, in the first winners could choose between getting paid $1 \$$ for sure or $1 \%$ of chance to win $100 \$$, in the second between getting $100 \$$ for sure or $1 \%$ of chance to win $10,000 \$$. They found that a Flat Raffle scheme, i.e., when a constant lottery winning chance is set for a period during the morning commute, works the best and outperforms the optimal one-step toll when the population is overall slightly risk-seeking.

A relatively new area consists in using smartphones as a platform for promoting and performing IBTDM. The smartphones use allows to collect of information about trips, travel time, money spent, travel mode, and other useful information that permit to make incentives more personalized and effective. Smartphone applications can be an effective instrument to promote IBTDM projects focusing on the behavior change of users; customization, relevant and contextualized information and feedback, appealing design are important aspects to considers when influencing users' behavior in changing their habits through app mobiles [38]. Nowadays, many models have been developed to predict travel trip characteristics using locational and sensing data from smartphones [39]. The work of [40] presented "Tripod", a smartphone-based system to influence individuals' real-time travel decisions by offering information and incentives to optimize system-wide energy performance. Travelers receive incentives for a certain variety of travel options as route, mode, departure time, ridesharing, etc.; each option is related to real-time information; travelers are encouraged not only by the incentives but also by energy savings and impacts on the environment information associated to their choice. Refs. [41,42] presented the app mobile "Metropia", which aims to improve traffic flow and commuter travel times by incentivizing travelers to change their travel behavior and avoid traffic congestion. The system predicts future traffic conditions, applies a proprietary routing algorithm to find time-dependent shortest paths for different departure times, and, based on user requests, provides automobile travelers with multiple departure times and route choices; for each travel some points values are assigned, with higher points (and thus more valuable rewards) available for traveling during off-peak times and less congested routes, and lower points available for peak traffic travel times. Ref. [43] analyzed a mobile application called Quantified Traveler (QT), which is a computational travel feedback system. Travel feedback is an established programmatic method whereby travelers record travels in diaries and meet with a counselor who guides the user to an alternate mode or trip decisions that are more sustainable or otherwise beneficial to society, while still meeting the subject's mobility needs. The study of [44] focused on how different types of personalized incentives jointly help alleviate peak-hour traffic and save time; using data from "Metropia" app, they examined the effects of incentives and results show that, based on real-time information, users rely more on expected time savings to adjust travel plans to eventually save time. Moreover, economic incentives encourage peak avoidance and help save travel time, but the dependence on rewards to avoid peak-hour traffic increases over time. 
From the literature, it arises that many studies present projects about IBTDM strategies. The novelty of this study is related to the integrated IBTDM framework, which involves not only the public administrations and citizens but also companies and local shops. Main IBTDM strategies are intended for citizens in general and they carry out benefits for them and the environment. The integrated methodological framework here presented, instead, generates a circular economy with benefits, economic and environmental, not only for citizens but also for the local economy and companies. In this way, the sustainable objective is encouraged by more actors and the project success is more achievable. Moreover, the project here presented considers the integrated use of a mobile app to monitor movements and provide the possibility to accumulate and spend incentives in local shops.

\section{IBTDM Methodological Framework for Sustainable People Home-Work Logistics}

This section aims to define an integrated Incentive-Based Traffic Demand Management (IBTDM) framework. The mobility flows interested by the project are the home-work logistics of the workers employed in the local companies. Table 1 reports the main characteristics of the considered IBTDM model, summarized by objectives, novelty elements, actors, and mobility systems.

Table 1. Main characteristics of the proposed IBTDM model.

\begin{tabular}{cccc}
\hline Objectives & Novelty Elements & Actors & Mobility Systems \\
\hline $\begin{array}{c}\text { Promotion of } \\
\text { sustainable mobility } \\
\text { systems and well-being }\end{array}$ & Scalability & $\begin{array}{c}\text { Local } \\
\text { Administrations }\end{array}$ & $\begin{array}{c}\text { Bicycle (traditional } \\
\text { or electric) }\end{array}$ \\
\hline $\begin{array}{c}\text { Traffic decongestion } \\
\text { and improvement of air } \\
\text { quality }\end{array}$ & $\begin{array}{c}\text { Self-sustainability } \\
\text { (Economical and } \\
\text { operational) }\end{array}$ & Local Companies & $\begin{array}{c}\text { Scooter (traditional } \\
\text { or electric) }\end{array}$ \\
\hline $\begin{array}{c}\text { Human-centred city } \\
\text { versus car-centred city }\end{array}$ & $\begin{array}{c}\text { Territorial circular } \\
\text { economy }\end{array}$ & Local Workers & Foot \\
\hline $\begin{array}{c}\text { Incentive to the local } \\
\text { economy and }\end{array}$ & $\begin{array}{c}\text { Public-private } \\
\text { integration }\end{array}$ & Local Shops & $\begin{array}{c}\text { Potential extension to } \\
\text { other sustainable } \\
\text { mobility systems }\end{array}$ \\
\hline
\end{tabular}

The proposed IBTDM methodological framework considers various sustainable mobility systems (bicycle, scooter, foot, etc.), promoting well-being supporting physical activity. The perspective moves to a human-centred city versus car-centred city. Traffic decongestion and improvement of air quality are achieved together with incentives to the local economy.

The actors are local administrations, companies, shops, and workers, with a publicprivate integration.

The main novelty elements, as reported in Table 1, are:

- Scalability: the IBTDM methodological framework can be extended thanks to the possibility to add new territories to the project and consequently new actors.

- Self-sustainability: the IBTDM methodological framework is based on incentives funded by the same actors of the project, i.e., public administrations and companies; moreover, the time and the fund values do not influence the adapted methodology. The operative issues are guaranteed by a third party, external to the actors but controlled by them, that manages, controls, and supports all the processes, even through the Internet of things (IoT).

- Territorial circular economy: the IBTDM methodological framework is based on incentives funded by territorial actors (local administrations and companies), that can be used only in territorial shops.

- Public-private integration: the IBTDM methodological framework is based on strong integration between public (local administrations) and private (companies, shops, 
workers) actors, supporting a territorial and social company model, which actively participates in the well-being of citizens and the good administration of the territory. The actors' involvement in the IBTDM system is reported in Figure 1.

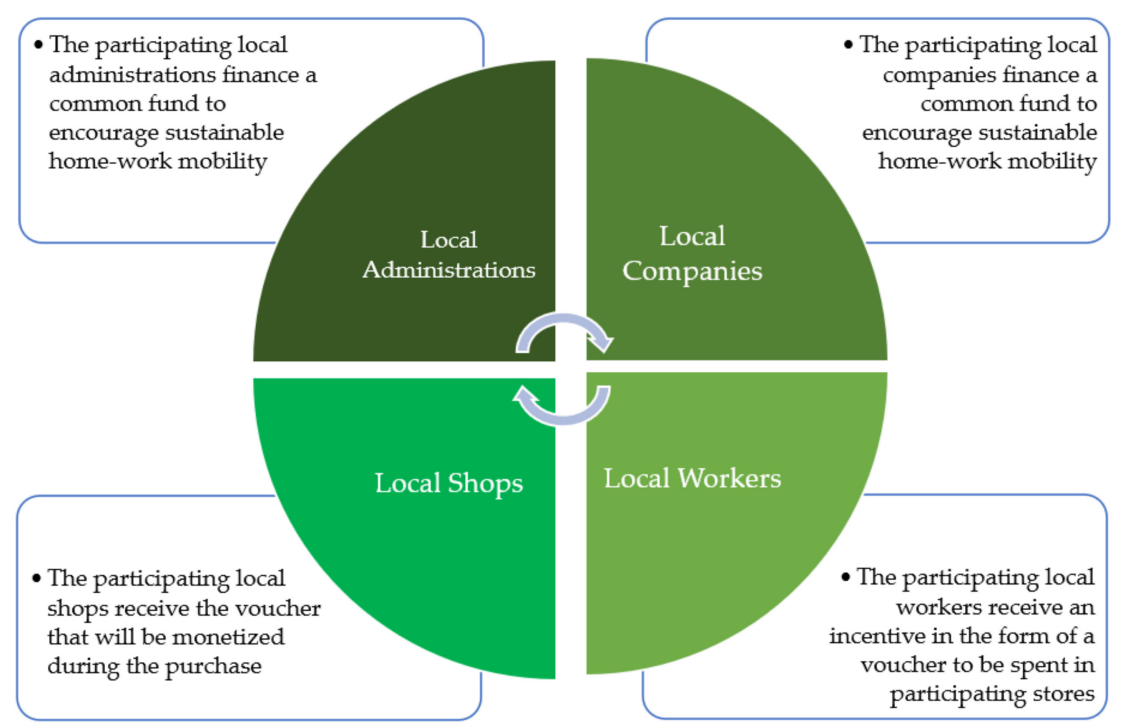

Figure 1. Actors' involvement in the proposed IBTDM system.

Figure 2, instead, shows the framework of the IBTDM model, with the main flows of activities between the different actors. The management and control of the entire system are left to a third-party entity, which is controlled by the actors, and which manages, controls, and supports all the processes, included the mobile App that monitors the home-work workers' travels, accumulates the incentives, and permits shopping at the local shops. Figure 3 reports some examples of the mobile app's screens developed for the case study reported in the next section.

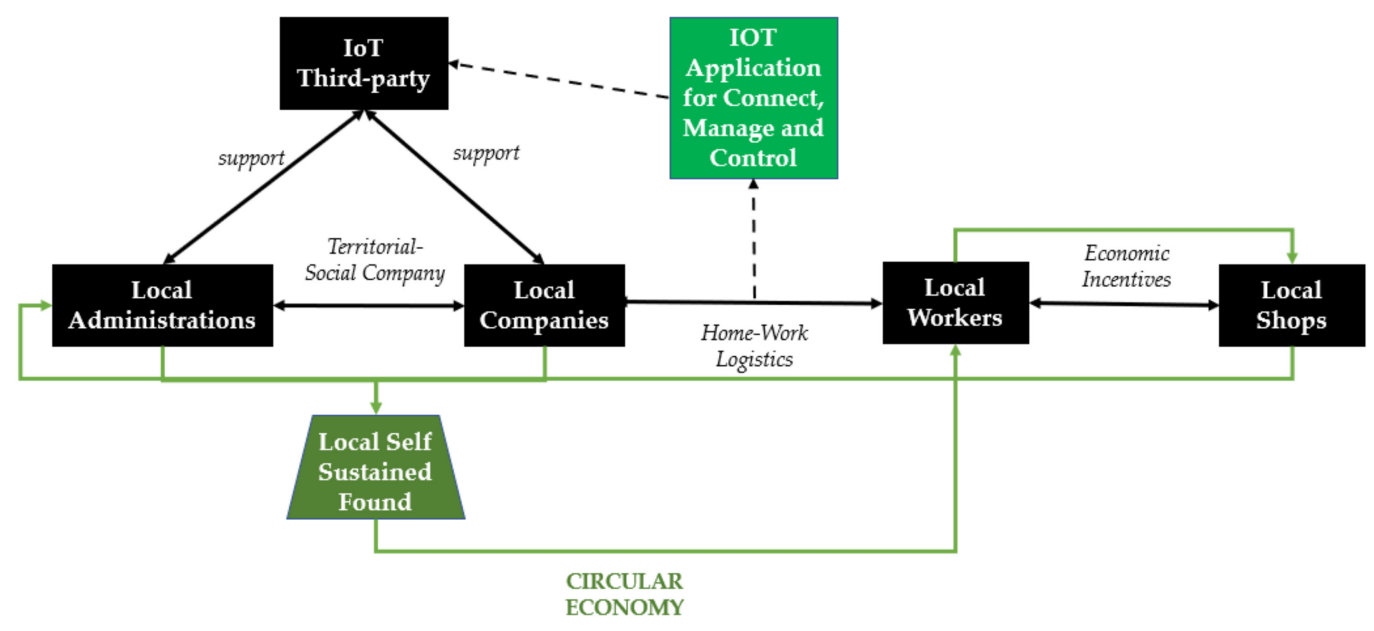

Figure 2. IBTDM methodological framework supported by the mobile App ECOATTIVI and by the IoT technologies. 

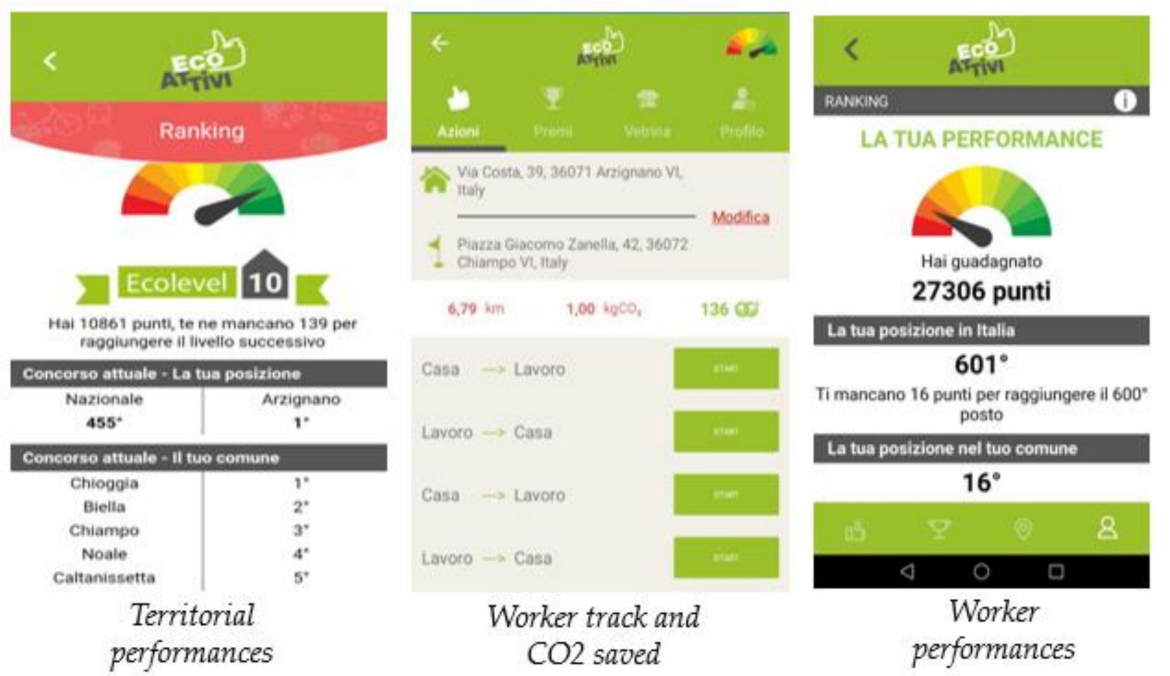

Figure 3. App screen with territorial performance, worker's track and performances.

The participating local administrations and companies finance a fund to incentive the home-work logistics. The participating workers are monitored, thanks to an application that integrates the Global Positioning System (GPS) in the smartphone, during the homework travels. For each kilometer that the worker travels by using one of the sustainable mobility systems reported in Table 1, an economic gain is accumulated. For example, in the case study, it is equal to $0.23 € / \mathrm{km}$. The use of cycle and pedestrian paths, as well as the average and maximum speed, are monitored to control the real utilization of sustainable mobility systems. The incentive is managed electronically in form of vouchers that can be spent in local shops. Once the incentive reaches, as an effect of the total distance covered, the value of $10 €$, the voucher is created and usable at the local shops. The transparency is guaranteed by the availability of data of each actor, especially in terms of money flows from the fund to workers or the shops. The data about the effect on the environment, like the saved $\mathrm{CO}_{2}$, is reported in the mobile app.

Finally, the worker competes in a special sustainability ranking. The same for companies, administrations, and shops aggregating the relative data. As a secondary incentive, the winner of these special rankings can gain sustainable awards.

If we analyze the entire value generated by the proposed IBTDM methodological framework, it is possible to consider an integrated pyramidal perspective, summarized in Figure 4. The basic value is territorial sustainability. The control model is developed according to economic and environmental results and the IoT technologies utilization, by using workers' smartphones. The common territorial advantages are related to the development of a territorial circular economy and an integrated social model where all the actors act together for a good administration of the territory. At the end, each actor will have specific benefits:

- Local Administrations: improvement of traffic flow in the area, especially during peak hours; model of incentives for their citizens.

- Local Companies: better traffic fluidity on the roads for the circulation of their goods and less area needed for company car parks; model of incentives for their employees.

- Local Workers: Reduction of queue times and potentially of time for moving from home to work, with preserving one's independence in mobility (i.e., bicycle); Possible increase of monthly income.

- Local Shops: Improvement of traffic flows in the area, especially in the city centre where the shops are located; a possible increase of monthly income. 


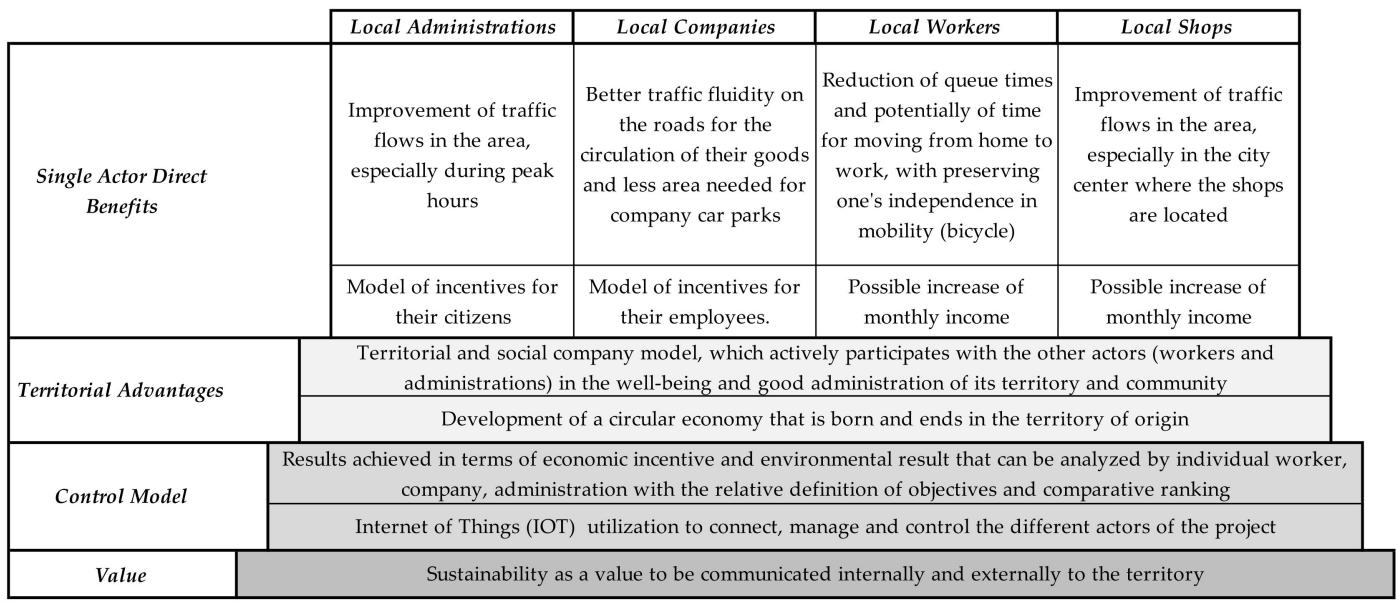

Figure 4. Value and benefits generated by the proposed IBTDM methodological framework.

\section{Case Study}

This section describes the application of the proposed IBTDM methodological framework in the Chiampo Valley, in the Veneto region, Italy. The project called "Bike to Work Valchiampo" (Figure 5, left side) started in 2019 with the feasibility study, with a break in 2020 for the Covid pandemic and the implementation in the summer of 2021. In this area, a cycle and pedestrian path go close to the Chiampo river along the valley (Figure 5, right side). This infrastructure permits the easy implementation of the IBTDM methodological framework considering the bicycle as the principal sustainable mobility system among those reported in Table 1.
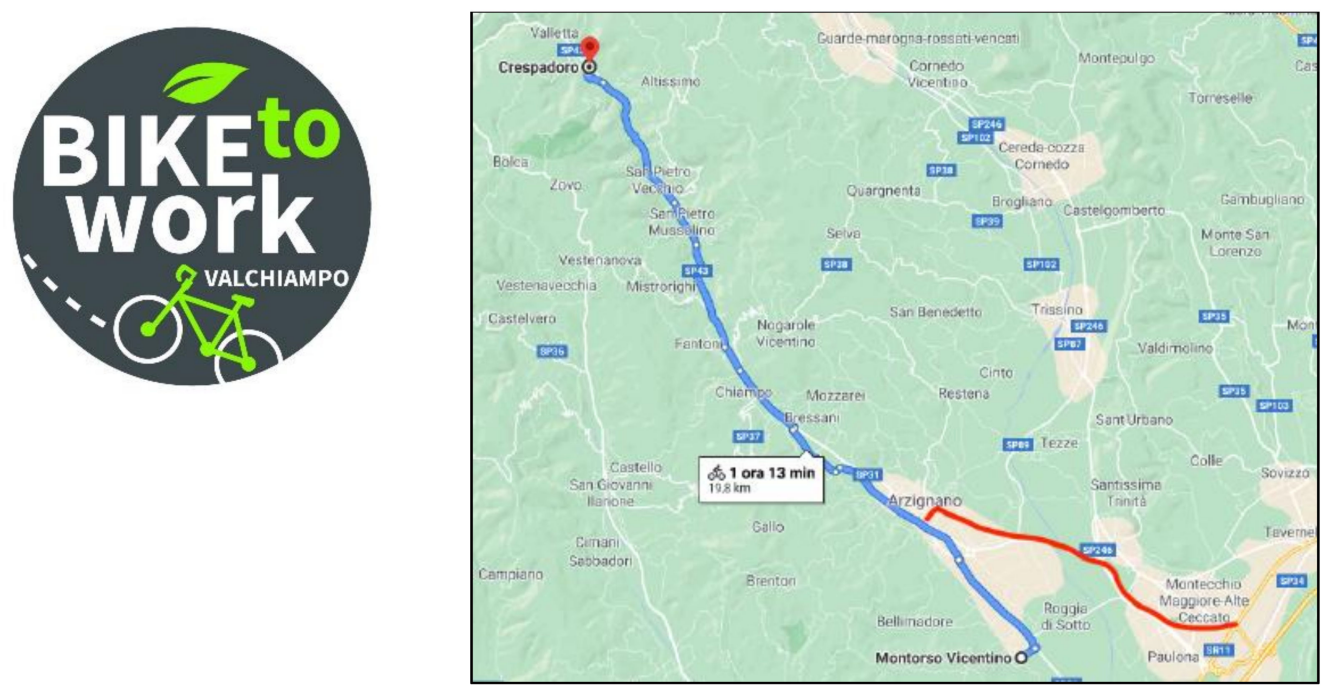

Figure 5. "Bike to Work Valchiampo" project (left) and cycle and pedestrian path in the Chiampo Valley (right) (source: Google Maps).

The project involves different local administrations, economic and social associations, companies, and shops, with a total population of about 70.000 people. Some elements forced these actors in finding strategies for sustainable people's home-work logistics.

As a first element, the valley morphology forced cars to move along a unique main street, with the effect of high peaks of traffic (up to 1400 vehicles/hour) during the traditional workers' home-work travels. Figure 6 reports in different colors the vehicle 
average speed during the 17:00-18:00 time window (in red the queues of vehicles created by high traffic).

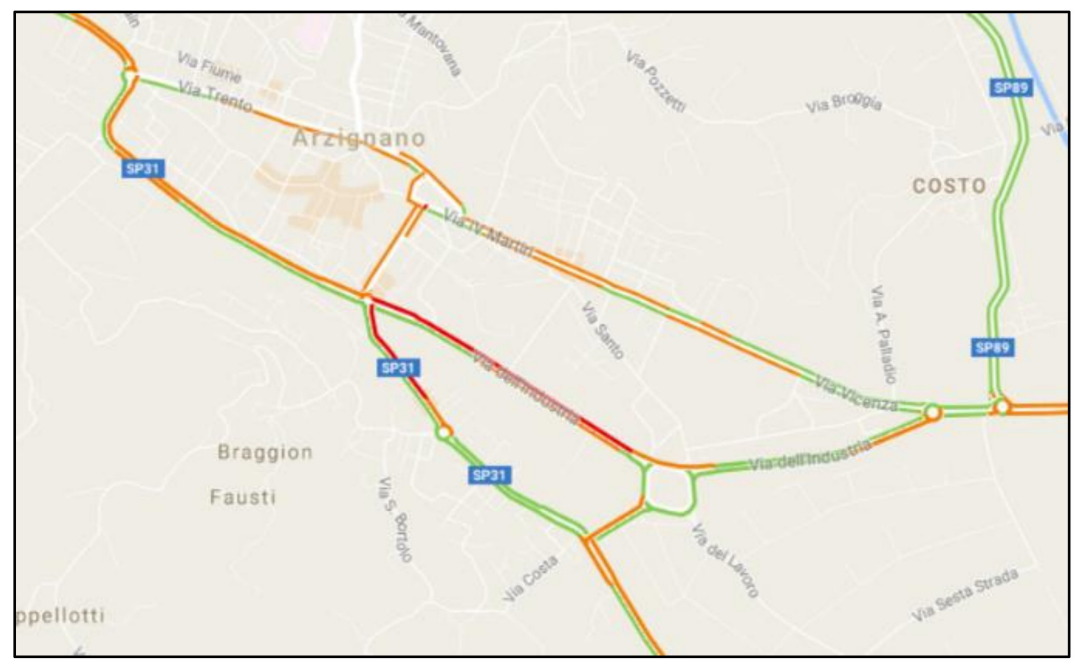

Figure 6. Vehicle average speed during the 17:00-18:00 time window, with queues in red (Source: Google Maps).

As a second element, because of the culture and of the traditional people behavior, the average number of people for each car, moving in that time windows, is 1.18 people/car [45]. Consequently, the effect of moving one person to a sustainable mobility mode (i.e., bicycle) is to eliminate one car from the streets.

As a third element, the considered area is one of the most industrialized areas of Italy, and the inefficiencies of the transport system negatively impact the competitiveness of the local companies.

In the first step of this project, about 150 companies have been involved to understand the interest in this project. Parallelly, about 680 workers have been involved. These workers are all the workers employed in the 150 companies. As consequence, the sample is well representative of the different patterns of workers in terms of age, gender, type of job, homework distance, etc. Using an online questionnaire, once described the main characteristics of the project, the basic questions about the interest in precipitating and funding (companies) and in participating and in using sustainable mobility systems (workers) have been asked. Table 2 reports the results. As we can see 40 companies out of 154 decided to participate in the questionnaire phase and just 17 out of 40 were interested in the project. Considering workers' perspectives only 204 out 680 decided to answer the questionnaire and $90 \%$ of them were interested in the project. The relatively low rate of responding companies and workers is due to the passive methodology adopted for the questionnaire administration. As shown in the last column of the table, the bicycle transportation system was the most required by workers, even if the carpooling presents interesting percentages that open the possibility to extend the project also to this mobility method. Finally, just a worker considers public transport as a potential sustainable transportation system.

Table 2. Project questionnaire results.

\begin{tabular}{|c|c|c|c|c|c|c|c|c|}
\hline \multicolumn{3}{|c|}{ Companies } & \multicolumn{3}{c|}{ Workers } & \multicolumn{3}{c|}{ Potential Sustainable Transportation } \\
System
\end{tabular}


The project started formally at the beginning of August 2021 and will end its experimental phase at the end of 2023. It is currently in its first stage of implementation. The total yearly budget for the experimental phase is equal to $100,000 €$ funded for about $50 \%$ by Local Administrations and the other $50 \%$ by the local companies. These actors together with the local shops and the economic and social associations signed a project agreement that defines the tasks and the objectives that each one will develop, according to the IBTDM methodological framework previously described.

During the first weeks of the project implementation, the number of participant workers constantly increasing with an increment of about 30 people each week. About 5 new local companies are added for each week.

The basic data collected from the mobile app shows the following data:

- Average daily home-work trip for each worker: $3.82 \mathrm{Km}(3.82 \mathrm{Km}$ home-work and 3.82 work-home), with a minimum value of $1.02 \mathrm{Km}$ and a maximum value of $8.71 \mathrm{Km}$.

- Average daily economic benefit for workers: $1.8 € /$ day (about $40 € /$ month)

- Average daily $\mathrm{CO}_{2}$ saved for workers: $1016 \mathrm{Kg}$ (about $22.36 \mathrm{Kg} / \mathrm{month}$ )

The first results demonstrate the potential benefits of the proposed IBTDM. The potential $\mathrm{CO}_{2}$ saved for a month is equal to 2.5 tons.

These first results in the bike to work project are encouraging and shows an impact on the traffic levels. Figure 7 reports the traffic jam at 7:30 before (up) and after (down) the implementation of the project. It can be noticed that the orange part (slow traffic flows) is reducing.

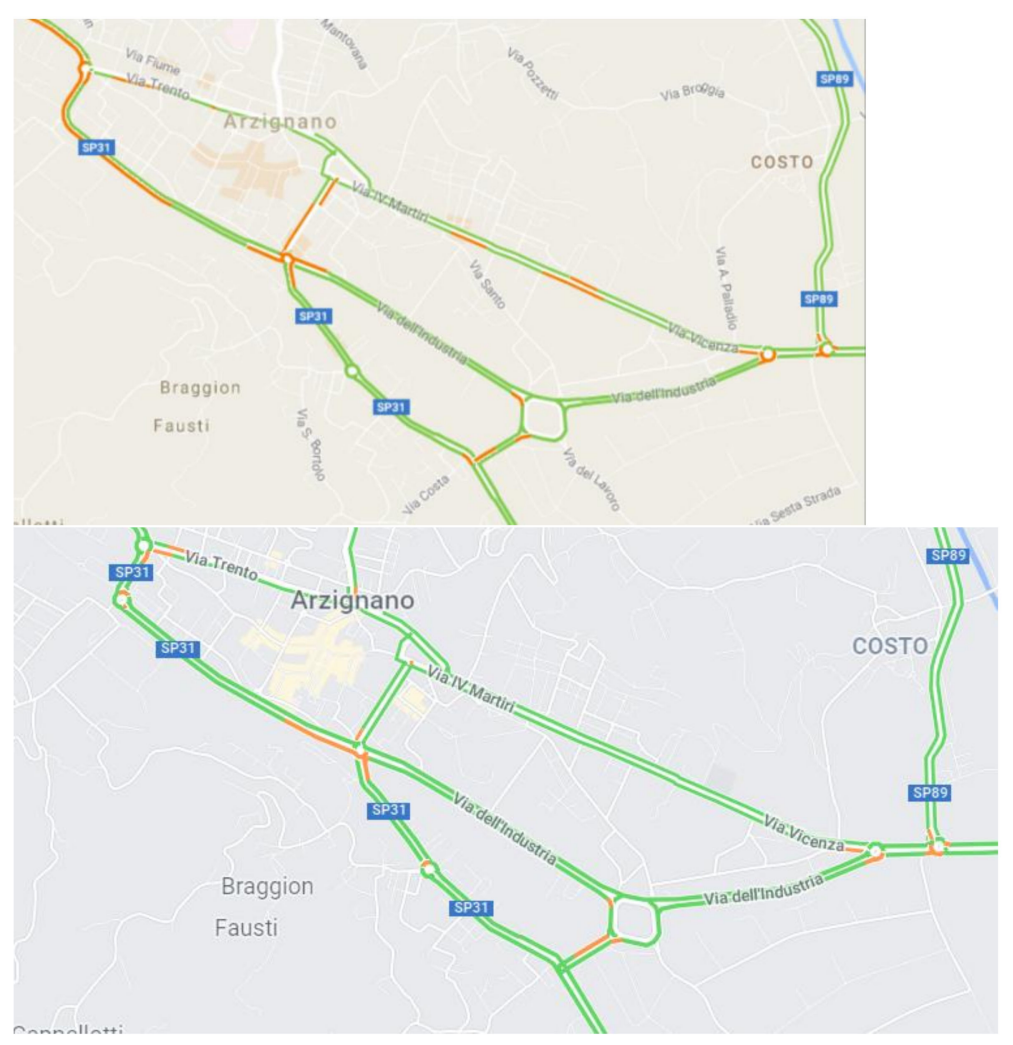

Figure 7. Vehicle average speed during at 7:30 before (up) and after (down) the Bike to Work project implementation with slow flows in orange (Source: Google Maps).

\section{Conclusions}

This paper proposes an integrated IBTDM methodological framework where 3 actors (companies, public administrations, and local shops) work together to economically incentivize the use of sustainable mobility systems. The sustainable people home-work logistics framework proposed aims to promote workers in using bicycles (and potentially 
other sustainable mobility systems) for the home-work logistics with incentives that can be used in the neighboring shops. In this way, not only the traffic congestion is reduced, but also it encourages a local circular economy generated thanks to the incentive's destinations; the framework is characterized by the economic self-sustainability of the incentives and the scalability, thanks to the possibility to add new territories to the project. Participant workers are monitored by a mobile app during the home-work journeys, analyzing the sustainable mobility and proving the possibility to accumulate and spend incentives in local shops. Incentives are a function of the saved $\mathrm{CO}_{2}$. On the other hand, companies and public administrations compete in a special ranking for sustainable mobility. This ranking can be visible inside the app and motivate all the actors in environmentally virtuous behaviour. The framework has been applied to a real case study in the Chiampo Valley, in the northeast of Italy, where about 10 different small towns and dozens of companies in 2020 started the "Bike to Work Valchiampo" project. Preliminary results, related to the first month of the project, are promising and new workers and companies want to be included in the project. For sure, it is necessary to monitor app data continuously and evaluate also benefits in terms of traffic congestions reduction. Surely, at the end of the experimental phase, collected data will be analyzed to investigate benefits and provide some useful guidelines. Moreover, as future steps, another sustainable transportation system might be taken into account to extend the project to workers that cannot use the bike for their home-work journeys.

The results of the case study will be disseminated once the project will end its experimental phase at the end of 2023.

Author Contributions: The corresponding author M.F. was responsible for planning and coordinating the steps of the research. All the authors, M.F., S.F., I.Z., were responsible for writing and reviewing this paper, together with the quantitative model proposal. All authors have read and agreed to the published version of the manuscript.

Funding: This research received no external funding.

Institutional Review Board Statement: Not applicable.

Informed Consent Statement: Not applicable.

Data Availability Statement: Contact the authors.

Acknowledgments: We acknowledge the Comune di Chiampo, Comune di Arzignano, Comune di Montecchio Maggiore, Comune di Montorso Vicentino, Comune di San Pietro Mussolino, Provincia di Vicenza, CNA Veneto Ovest, Confindustria Vicenza, Confartigianato Vicenza, Confcommercio Vicenza. We also acknowledge Achab Group and Ecoattivi for their support during the "Bike to Work Valchiampo" project.

Conflicts of Interest: The authors declare no conflict of interest.

\section{References}

1. Witchayaphong, P.; Pravinvongvuth, S.; Kanitpong, K.; Sano, K.; Horpibulsuk, S. Influential factors affecting travelers' mode choice behavior on mass transit in Bangkok, Thailand. Sustainability 2020, 12, 522. [CrossRef]

2. Wei, Y.; Huang, C.; Lam, P.T.I.; Sha, Y.; Feng, Y. Using urban-carrying capacity as a benchmark for sustainable urban development: An empirical study of Beijing. Sustainability 2015, 7, 3244-3268. [CrossRef]

3. Kumar, V.; Bhat, C.R.; Pendyala, R.M.; You, D.; Ben-Elia, E.; Ettema, D. Impacts of incentive-based intervention on peak period traffic: Experience from the Netherlands. Transp. Res. Rec. 2016, 2543, 166-175. [CrossRef]

4. Sun, J.; Wu, J.; Xiao, F.; Tian, Y.; Xu, X. Managing bottleneck congestion with incentives. Transp. Res. Part B Methodol. 2020, 134, 143-166. [CrossRef]

5. Litman, T. The Online TDM Encyclopedia: Mobility management information gateway. Transp. Policy 2003, 10, 245-249. [CrossRef]

6. Higgins, T.J. Demand management in suburban settings. Transportation 1990, 17, 93-116. [CrossRef]

7. Tian, Y.; Li, Y.; Sun, J.; Ye, J. Characterizing favored users of incentive-based traffic demand management program. Transp. Policy 2021, 105, 94-102. [CrossRef]

8. Bauer, J.; Bedsole, L.K.; Snyder, K.; Neuner, M.; Smith, M.C. Expanding Traveler Choices through the Use of Incentives: A Compendium of Examples; US Department of Transportation: Washington, DC, USA, 2018. Available online: https://ops.fhwa.dot.gov/ publications / fhwahop18071/index.htm\#toc (accessed on 8 July 2021). 
9. Ben-Elia, E.; Ettema, D. Carrots versus sticks: Rewarding commuters for avoiding the rush-hour-a study of willingness to participate. Transp. Policy 2009, 16, 68-76. [CrossRef]

10. Koppelman, F.S.; Bhat, C.R.; Schofer, J.L. Market research evaluation of actions to reduce suburban traffic congestion: Commuter travel behavior and response to demand reduction actions. Transp. Res. Part A 1993, 27, 383-393. [CrossRef]

11. Tsirimpa, A.; Polydoropoulou, A.; Pagoni, I.; Tsouros, I. A reward-based instrument for promoting multimodality. Transp. Res. Part F Traffic Psychol. Behav. 2019, 65, 121-140. [CrossRef]

12. Chang, G.L.; Mahmassani, H.S. Travel time prediction and departure time adjustment behavior dynamics in a congested traffic system. Transp. Res. Part B 1988, 22, 217-232. [CrossRef]

13. Saleh, W.; Farrell, S. Implications of congestion charging for departure time choice: Work and non-work schedule flexibility. Transp. Res. Part A Policy Pract. 2005, 39, 773-791. [CrossRef]

14. Hashemi, H.; Abdelghany, K. Real-time traffic network state prediction for proactive traffic management: Simulation experiments and sensitivity analysis. Transp. Res. Rec. 2015, 2491, 22-31. [CrossRef]

15. Abdelghany, K.; Hashemi, H.; Khodayar, M.E. A decision support system for Proactive-Robust traffic network management. IEEE Trans. Intell. Transp. Syst. 2018, 20, 297-312. [CrossRef]

16. Le, T.; Vu, H.L.; Walton, N.; Hoogendoorn, S.P.; Kovács, P.; Queija, R.N. Utility optimization framework for a distributed traffic control of urban road networks. Transp. Res. Part B Methodol. 2017, 105, 539-558. [CrossRef]

17. Wang, J.; Chi, L.; Hu, X.; Zhou, H. Urban traffic congestion pricing model with the consideration of carbon emissions cost. Sustainability 2014, 6, 676-691. [CrossRef]

18. Bonsall, P.; Shires, J.; Maule, J.; Matthews, B.; Beale, J. Responses to complex pricing signals: Theory, evidence and implications for road pricing. Transp. Res. Part A Policy Pract. 2007, 41, 672-683. [CrossRef]

19. Schaller, B. New York City's congestion pricing experience and implications for road pricing acceptance in the United States. Transp. Policy 2010, 17, 266-273. [CrossRef]

20. Gneezy, U.; Rustichini, A. A fine is a price. J. Legal Stud. 2000, 29, 117. [CrossRef]

21. Mahmassani, H.S.; Zhou, X.; Lu, C.C. Toll pricing and heterogeneous users: Approximation algorithms for finding bicriterion time-dependent efficient paths in large-scale traffic networks. Transp. Res. Rec. 2005, 1923, 28-36. [CrossRef]

22. Small, K.A.; Yan, J. The value of 'value pricing' of roads: Second-best pricing and product differentiation. J. Urban Econ. 2001, 49, 310-336. [CrossRef]

23. Lam, T.C.; Small, K.A. The value of time and reliability: Measurement from a value pricing experiment. Transp. Res. Part E Logist. Transp. Rev. 2001, 37, 231-251. [CrossRef]

24. Phang, S.Y.; Toh, R.S. From manual to electronic road congestion pricing: The Singapore experience and experiment. Transp. Res. Part E Logist. Transp. Rev. 1997, 33, 97-106. [CrossRef]

25. Lin, X.; Susilo, Y.O.; Shao, C.; Liu, C. The implication of road toll discount for mode choice: Intercity travel during the Chinese spring festival holiday. Sustainability 2018, 10, 2700. [CrossRef]

26. Ramandanis, I.D.; Politis, I.; Basbas, S. Assessing the environmental and economic footprint of electronic toll collection lanes: A simulation study. Sustainability 2020, 12, 9578. [CrossRef]

27. Li, X.; Lv, Y.; Sun, W.; Zhou, L. Cordon- or link-based pricing: Environment-oriented toll design models development and application. Sustainability 2019, 11, 258. [CrossRef]

28. Brumercikova, E.; Bukova, B.; Nedeliakova, E. A proposal for the account-based ticketing application in passenger transport in the Slovak Republic: A case study. Sustainability 2020, 12, 5491. [CrossRef]

29. Faccio, M.; Persona, A.; Sgarbossa, F.; Zanin, G. Multi-stage supply network design in case of reverse flows: A closed-loop approach. Int. J. Oper. Res. 2011, 12, 157-191. [CrossRef]

30. Wu, J.; Tian, Y.; Sun, J. A bilevel programming framework for determining the optimal incentive-based traffic demand management strategy. In Proceedings of the 19th COTA International Conference of Transportation Professionals (CICTP 2019: Transportation in China-Connecting the World), Nanjing, China, 6-8 July 2019; pp. 5900-5912. [CrossRef]

31. Arian, A.; Ermagun, A.; Zhu, X.; Chiu, Y.-C. An Empirical Investigation of the Reward Incentive and Trip Purposes on Departure Time Behavior Change. In Advances in Transport and Policy; Elsevier: Amsterdam, The Netherlands, 2018. [CrossRef]

32. Merugu, D.; Prabhakar, B.S.; Rama, N. An Incentive Mechanism for Decongesting the Roads: A Pilot Program in Bangalore. In Proceedings of the NetEcon Workshop, Stanford, CA, USA, 7 July 2009.

33. Ettema, D.; Knockaert, J.; Verhoef, E. Using incentives as traffic management tool: Empirical results of the 'peak avoidance' experiment. Transp. Lett. 2010, 2, 39-51. [CrossRef]

34. Ben-Elia, E.; Ettema, D. Changing commuters' behavior using rewards: A study of rush-hour avoidance. Transp. Res. Part F Traffic Psychol. Behav. 2011, 14, 354-368. [CrossRef]

35. Bamberg, S.; Ajzen, I.; Schmidt, P. Choice of Travel Mode in the Theory of Planned Behavior: The Roles of Past Behavior, Habit, and Reasoned Action. Basic Appl. Soc. Psych. 2003, 25, 175-187. [CrossRef]

36. Sun, Y.; Zhang, L. Microeconomic model for designing public transit incentive programs. Transp. Res. Rec. 2018, 2672, 77-89. [CrossRef]

37. Zhang, P.; Qian, Z. Managing traffic with raffles. Transp. Res. Part C Emerg. Technol. 2019, 107, 490-509. [CrossRef]

38. Andersson, A.; Hiselius, L.W.; Adell, E. Promoting sustainable travel behaviour through the use of smartphone applications: A review and development of a conceptual model. Travel Behav. Soc. 2018, 11, 52-61. [CrossRef] 
39. Ermagun, A.; Fan, Y.; Wolfson, J.; Adomavicius, G.; Das, K. Real-time trip purpose prediction using online location-based search and discovery services. Transp. Res. Part C Emerg. Technol. 2017, 77, 96-112. [CrossRef]

40. Azevedo, C.L.; Seshadri, R.; Gao, S.; Atasoy, B.; Akkinepally, A.; Christofa, E.; Zhao, F.; Trancik, J.; Ben-Akiva, M. Tripod: Sustainable Travel Incentives with Prediction, Optimization, and Personalization. In Proceedings of the 97th Annual Meeting Transportation Research Board, Washington, DC, USA, 7-11 January 2018; Volume 1, p. 19.

41. Hu, X.; Chiu, Y.C.; Zhu, L. Behavior Insights for an Incentive-Based Active Demand Management Platform. Int. J. Transp. Sci. Technol. 2015, 4, 119-133. [CrossRef]

42. Hu, X.; Zhu, X.; Chiu, Y.C.; Tang, Q. Will information and incentive affect traveler's day-to-day departure time decisions?-An empirical study of decision making evolution process. Int. J. Sustain. Transp. 2020, 14, 403-412. [CrossRef]

43. Jariyasunant, J.; Abou-Zaied, M.; Carrel, A.; Venkatesan, E.; Gaker, D.; Sengupta, R.; Walker, J.L. Quantified traveler: Travel feedback meets the cloud to change behavior. J. Intell. Transp. Syst. Technol. Plan. Oper. 2015, 19, 109-124. [CrossRef]

44. Li, T.; Chen, P.; Tian, Y. Personalized incentive-based peak avoidance and drivers' travel time-savings. Transp. Policy 2021, 100, 68-80. [CrossRef]

45. Diversamente in Movimento. Study Developed in Collaboration with the University of Padova. 2017. Available online: https: / / www.confartigianatovicenza.it/diversamente-in-movimento-uno-studio-per-una-migliore-viabilita-nella-valle-delchiampo-voluto-da-confartigianato-e-comuni-di-arzignano-e-chiampo (accessed on 12 August 2021). 